\title{
OECD gives Japan mixed score on environment
}

Tokyo. Japan's efforts to preserve its environment over the past several decades have been both praised and criticized in a comprehensive review by the Organization for Economic Cooperation and Development (OECD). The report points out that over the past two decades Japan has achieved the fastest economic growth among advanced nations, but despite industrial success has shown the best performance among OECD countries in reducing emissions of a number of pollutants.

At the same time, however, the 210-page report focuses on a number of severe shortcomings of Japan's environmental performance. Waste-water treatment comes in for particular criticism. Only 44 per cent of Japan's population are served by wastewater treatment plants, and many people (63 per cent) do not have flush toilets.
The report points out that since 1970 SOx emissions have fallen 82 per cent and $\mathrm{NOx} 21$ per cent, and $\mathrm{CO}_{2}$ emissions are among the lowest for OECD nations calculated per capita and per unit of gross domestic product. This decoupling of economic growth and emissions of pollutants is held up as a shining example for other nations to follow.

The report explains that it has been achieved through a combination of regulatory measures, by both central and local government, more efficient use of energy by industry and the spread of desulphurization and denitrification technology.

Changes in the structure of the national economy away from heavy polluting industry and greater use of non-fossil fuel energy sources, such as hydropower and nuclear power, have also played an important role.

\section{Gene therapists face double check}

Tokyo. University medical researchers in Japan are at last in a position to start preparing for the application of gene therapy techniques to patients, following the setting up of a screening committee by the Ministry of Education, Science and Culture (MESC), which has jurisdiction over universities.

The first meeting of the committee was held in Tokyo last week. Its establishment completes the formation of a government regulatory system for gene therapy in Japan. But, in a typical example of the bureaucratic duplication of effort that occurs in central government, proposals from university researchers will also have to be screened by another similar committee, with overlapping members, established in February by the Ministry of Health and Welfare (MHW) (Nature 367, 502; 1994).

The MESC committee is headed by Yoshio Okada, chairman of the Senri Life Science Foundation in Osaka. Among its 16 members are Kenichi Matsubara of Osaka University, Kumao Toyoshima, head of the Center for Adult Disease in Osaka, and Fumimaro Takaku, head of the International Medical Center of Japan in Tokyo, who also serve on the MHW committee.

But there are only three non-scientists on the ministry of education committee, as opposed to five in the MHW committee. This is likely to result in a differing focus for the two committees, and it remains to be seen whether the two committees always agree in their decisions.

Some scientists, including one member of both committees, fear the MHW committee, with its larger compliment of non-scientists, may get bogged down in the politics of social and ethical issues. They feel that, as gene therapy techniques will not be applied to reproductive cells, only the safety and scientific and medical soundness of proposed applications of gene therapy needs to be considered.

But some other key members of the MHW committee consider it important to pay attention to social and ethical issues, and the make-up of the committee, which includes a well-known writer, Ayako Sono, and a former journalist, reflects this view.

In contrast, the MESC committee seems likely to concentrate more on scientific issues. Shin-ichi Ota, of MESC's grant-in-aid planning office, says the main purpose of the MESC committee is to provide expert advice on the safety and soundness of proposals from an "academic" point of view. Social and ethical issues will be debated "where necessary", he says, but coverage of these issues will be "thinner" than in the MHW committee. David Swinbanks

\section{Indian medicine to head back to its roots?}

New Delhi. Medical research in India is likely to find itself heading in new directions with the appointment of $G$. V. Satyavati as the first woman to head the Indian Council of Medical Research (ICMR).

Satyavati holds two MD degrees, one in pharmacology and the other in ayurveda, a system of ancient wisdom. The combination has provided a basis for her extensive studies of the medicinal values of herbs, and helped her to apply modern tests to traditional cures. Her research, carried out over two decades, led to a herbal drug for treating high blood cholesterol. She was also responsible for manpower development at ICMR,
Water treatment, however, has not been a success. Much raw or poorly treated sewage is dumped into the sea, rivers and lakes, and most sewage treatment plants use primitive activated sludge processes that fail to remove phosphorus and nitrogen compounds.

Indeed, the report illustrates how, despite Japan's 1972 Nature Conservation Law, which states as a "unique cultural tradition of Japan" that "man, nature and man's works of art form an organic unity", there is little sign that this basic philosophy has been translated into action.

Over a 13-year period from 1973, for example, the area of Japan's natural forests decreased by 14 per cent due to development. Most of Japan's lakes have also suffered "severe alteration" during this period and more than 30 per cent of lake shorelines have been developed for industrial or urban use.

Seven hundred kilometres of coastline were modified artificially in the 1980 s, and less than half ( 46 per cent) of the coastline of Japan's four main islands remains in a natural state. More than a fifth ( 21.5 per cent $)$ of Japan's vertebrate species are either rare, vulnerable, endangered or extinct.

Two million hectares of land has been designated as "national parks" but commercial exploitation (ski tows, spas and golf courses) often occurs on private land within the parks, leading to significant environmental degradation. Japan has one of the lowest percentages (6.4 per cent) of protected land areas among OECD nations. And there is a severe shortage of manpower to look after these protected areas.

The report points out that the various ministries and agencies with responsibility for environmental matters "seem to act in a spirit of competition rather than working together", and it calls for greater cooperation and a comprehensive environmental plan at the national level. David Swinbanks

OECD Environmental Performance Reviews - Japan (210 pages, OECD, Paris, 1994).

and handled its publications.

Before her new appointment, she was deputy director-general of ICMR. Observers say her appointment as ICMR chief, where she was chosen in preference to more senior colleagues and others working at the cutting edge of medical technologies, indicates a desire by the government to boost traditional methods of health care.

Satyavati says her immediate priority is to improve medical research in colleges and to revitalize ICMR's many regional units. "We will also take a fresh look at the ethical issues of human and animal experiments," she says. K. S. Jayaraman 